\title{
Water-use efficiency of a mallee eucalypt growing naturally and in short-rotation coppice cultivation
}

\author{
Dan T. Wildy $1,2,3,5$, John S. Pate ${ }^{1,2}$ \& Lesley T. Sefcik ${ }^{2,4}$ \\ ${ }^{1}$ Cooperative Research Centre for Plant-Based Management of Dryland Salinity, University of Western Australia, \\ 35 Stirling Hwy, Crawley, WA 6009, Australia. ${ }^{2}$ School of Plant Biology, Faculty of Natural and Agricultural \\ Sciences, University of Western Australia, 35 Stirling Hwy, Crawley, WA 6009, Australia. ${ }^{3}$ Present address: Albany \\ Forestry Research Center, P.O. Box 1891, Albany, WA, 6331. ${ }^{4}$ Present address: School of Natural Resources \\ and Environment, University of Michigan, 430 E. University Ave, Ann Arbor, Michigan, 48109-1115, U.S.A. \\ ${ }^{5}$ Corresponding author*
}

Received 22 July 2003. Accepted in revised form 25 October 2003

Key words: alley farming, carbon isotope composition, carbon partitioning, semi-arid environment, stomatal conductance, starch utilization

\begin{abstract}
This study compared mature Eucalyptus kochii subsp. plenissima trees in inner regions or edges of natural bushland to young trees belt-planted through cleared agricultural land as uncut saplings or regenerating coppice over 2.7 years at Kalannie, Western Australia (320 mm annual rainfall). We assessed the ability of the species to alter its gas exchange characteristics, leaf physical attributes, and water-use efficiency of foliar carbon assimilation $\left(W U E_{i}\right)$ or of total dry matter production $\left(W U E_{D M}\right)$. Stomatal conductance $\left(g_{s}\right)$ varied five-fold between treatment means, with coppices exhibiting greatest values and mature bush least. Photosynthetic rates followed this trend. Leaf photosynthetic capacity estimated by chlorophyll content varied 1.3-fold parallel with variations in leaf thickness, with coppices rating lowest and mature edge trees most highly. $W U E_{i}$ varied 1.5 -fold between treatments and was greatest in mature inner-bush and edge trees. Leaf photosynthetic capacity and $g_{s}$ were both correlated with $W U E_{i}$. Carbon isotope composition $\left(\delta^{13} \mathrm{C}\right.$ values $)$ of new shoot dry matter produced early in a seasonal flush were similar to those of root starch but when averaged over the whole season correlated well with $W U E_{i}$ and gas exchange characteristics of trees of each treatment. Coppices showed poorest $W U E_{i}$ and most negative shoot tip $\delta^{13} \mathrm{C}$ but their $W U E_{D M}$ was high. This discrepancy was suggested to relate to carbon allocation strategies in coppices favouring fast growth of replacement shoots but not of roots. Physiology of coppice growth of E. kochii is usefully geared towards both rapid and water-use efficient production of woody biomass in water limited environments.
\end{abstract}

\section{Introduction}

Multi-stemmed 'mallee' eucalypts occur naturally across broad regions of southern Australia in Mediterranean-type climates where annual rainfall ranges from 300 to $450 \mathrm{~mm}$. In their native habitat they grow slowly (Walker et al., 1990), are very long lived (Tyson et al., 1998), and show excellent adaptations to low nutrient soils, periodic drought and high seasonal temperatures. These adaptive features include laterally

*FAX No. +61 898453158.

E-mail: dan@afrc.com.au extensive and deeply-penetrating root systems (Nulsen et al., 1986) and a sclerophyllous habit with foliage exhibiting tight stomatal control and related ability to withstand low leaf water potentials (Jones et al., 1981; Myers and Neales, 1984).

Whether in response to fire or artificial cutting, mallees are also renowned for their ability to resprout by means of regenerative shoot meristems on their lignotubers with energy initially provided from starch rich rootstocks (Noble, 2001; Wildy and Pate, 2002). This renders some of the more vigorous mallees such as Eucalyptus kochii Maiden \& Blakely 
subsp. plenissima Gardner (Brooker) potentially useful for co-production of bioenergy, activated carbon and eucalyptus oil when above-ground biomass is harvested on short rotations in semi-arid agricultural land (Enecon Pty Ltd., 2001). When belt-planted through shallow rooted crops and pastures, deep-rooted mallees have access to relatively abundant water sources accumulated in soil profiles or groundwater bodies (Wildy et al., in press) and should show heightened rates of growth compared to native stands.

While allowing mallees to survive in xeric natural environments, the physiological and structural adaptations such as those described above impose carbon costs that unspecialised species adapted to more mesic environments do not bear (Bradshaw, 1965; Pate et al., 1990; Prior et al., 1997). When mallees such as E. kochii are planted in habitats favourable in terms of water and nutrient supply, it remains to be seen whether growth rates are similarly encumbered or whether some degree of variability exists.

A number of reasonably well documented physiological effects arise when woody species are coppiced. Heightened growth rates relative to current leaf area are commonly observed during early stages of resprouting (Blake, 1983; Daniel et al., 1979; Kauppi et al., 1988; Sims et al., 1999), whether via improved water relations mediated by a large surviving root system (Blake, 1980; Kruger and Reich, 1993; SennerbyForsse et al., 1992; Tschaplinski and Blake, 1989) or increased inherent photosynthetic capacity per unit leaf area (e.g., DeSouza et al., 1986; Kauppi et al., 1990). As far as our study species is concerned, carbon allocation patterns in the first two years after decapitation clearly favour shoots over roots (Wildy and Pate, 2002) and may also contribute to high coppice growth rates.

The ideal woody or herbaceous species for water limited agricultural environments is generally regarded as exhibiting high water-use efficiency without penalties in terms of overall growth rate (Saranga et al., 1998; Xu et al., 2000). However, if the intrinsic water-use efficiency during carbon assimilation $\left(W U E_{i}\right)$ is high and attained principally through low stomatal conductance, potential rates of $\mathrm{CO}_{2}$ fixation are likely to be penalised (Farquhar et al., 1982; Gibson et al., 1994; Liu et al., 1996; Osório and Pereira, 1994). On the other hand, there may be circumstances in which differences in $W U E_{i}$ are related to leaf photosynthetic capacity and thereby engender increased photosynthetic rates (Clearwater and Meinzer, 2001; Farquhar et al., 1989b; Hubick, 1990; Xu et al., 2000).
It therefore becomes important to establish whether E. kochii does indeed exhibit the inherent capability to upgrade stomatal conductance and/or leaf photosynthetic capacity when experiencing better watered and fertilized conditions, and to assess how such features might affect $W U E_{i}$.

Notwithstanding the characteristics of a species in respect of its $W U E_{i}$, effectiveness of water use in generating biomass at the whole-plant level (WUE $\left.E_{D M}\right)$ remains the most relevant measure of usefulness in a water limited agricultural environment (Saranga et al., 1998). Carbon isotope ratios of dry matter (Farquhar et al., 1989a; Farquhar et al., 1982) have been used in this respect to measure long-term effectiveness in whole-plant water use (e.g., Xu et al., 2000). However, while $\delta^{13} \mathrm{C}$ values may correlate very well with intrinsic water-use efficiency at leaf level (Hubick, 1990; Le Roux et al., 1996; Zhang et al., 1993), poor relationships have also been encountered for eucalypt species when net biomass production has been compared with water consumed at whole-tree level (Le Roux et al., 1996; Olbrich et al., 1993; and see also Osório et al., 1998).

The literature on the water-use efficiency of resprouting woody species provides examples of higher $W U E_{D M}$ for coppices than for similarly aged uncut trees (e.g., see Eastham et al. (1994) for coppiced mallee eucalypts and Lindroth and Cienciala (1996) for resprouting Salix). The last named authors proposed that high water-use efficiency was due to high photosynthetic capacity of leaves of coppice canopies, as also suggested by Kauppi et al. (1990) for Betula. However, high rates of stomatal conductance or leaf transpiration associated with coppices of many other taxa including Eucalyptus (Allen et al., 1999; Bassman and Dickman, 1982; Blake, 1980; Hodgkinson, 1992; Karschon, 1971; Kruger and Reich, 1993) would be expected to denote low rather than high $W U E_{i}$ (e.g., Farquhar et al., 1989a; Fleck et al., 1995).

This study involved the mallee eucalypt E. kochii growing at a semi-arid site near Kalannie in the Western Australian wheatbelt. Mature specimens were present throughout remnant bushland bordering a large study paddock in which uncut saplings and coppiced trees had been alley-planted five years earlier. Our objective was to examine the variability of gas exchange, leaf photosynthetic capacity, and water-use efficiency of the species at leaf and whole-plant levels across these bush and agricultural settings. Our principal hypothesis was that the younger uncut or coppiced trees in better watered agricultural land should ex- 
hibit higher stomatal conductances than in the bush, and we expected limited variability in leaf photosynthetic capacity, so water-use efficiency at both leaf and whole-plant levels in the young trees would be reduced (see Farquhar et al., 1989a; Farquhar et al., 1982).

\section{Materials and methods}

\section{Site and treatments}

The study was located on a 100 ha paddock and adjacent bushland near Kalannie, in the Western Australian wheatbelt. The climate of the region is extradry Mediterranean (Beard, 1984) with a 74 year mean annual rainfall of $319 \mathrm{~mm}$ at Kalannie. Cooler 'winter' months (May-October) experience much lower vapour pressure deficits (VPD) than the hot 'summer' months (November-April) (see Figure 1). During the study period (February 1999 to October 2001) the site experienced aseasonal summer rainfall events in the first two summers, after which conditions were drier than usual (Figure 1).

Young E. kochii subsp. plenissima trees were planted in 1994 in twin-row belts through the paddock as detailed more fully by Wildy and Pate (2002). Wheat (1999) and volunteer pasture (subsequent years) grew in the alleys between tree belts. Belts were divided into 16 blocks, and three $100 \mathrm{~m}$ long quadrats were randomly assigned within each block to the following treatments: (i) coppice regeneration following decapitation in February 1999 ('CF'); (ii) coppice regeneration following decapitation in October 1999 ('CO'); or (iii) trees remaining as uncut saplings ('S') (see Table 1).

Mature, naturally occurring E. kochii subsp. plenissima trees were present throughout long unburnt natural bushland adjacent to the alley-planted paddock. The shoot systems of these trees were about 50 years old, having resprouted after the area had been chain-cleared in the 1950s. Trees of E. kochii in the bush remnants grew co-dominantly with other mallee species (E. sheathiana Maiden, E. subangusta (Blakely) Brooker \& Hopper subsp. subangusta, and E. hypoclamydea Brooker subsp. hypochlamydea ms), and with an understorey of Acacia-rich shrubs. Trees bordering the paddock were much larger than those located deeper within the bush, presumably as a result of increased availability of nutrients and water provided from the cleared agricultural land (see also situation recorded for Banksia woodland by Grigg et al. (2000)). We considered these larger 'edge' trees as simulating the likely future state of long-uncut tree belts within the paddock, while at the same time providing a contrast to mature trees within the waterand nutrient-impoverished bushland. Four individual trees (each comprising four to eight stems) of both mature inner-bush ('MB') and mature edge ('ME') treatments were selected for study, with a mobile, trailer-mounted scaffolding tower providing access to their canopies.

Leaf area index, shoot extension, relative growth rates and predawn water potentials

Leaf area of mature trees was measured nondestructively using the module method (see Andrew et al., 1979; Hatton et al., 1995). A pre-selected foliage 'module' from a non-target tree was used for estimation of the number of such modules in the canopy of each study tree, and the module then stripped for leaf biomass and area. This was carried out on five occasions using 4-6 observers and the method calibrated using additional trees whose whole canopies were later sampled destructively. For young belt-planted trees, corresponding leaf biomass and area data were available from the data set of Wildy et al. (2002). Leaf area indices of all treatments were then expressed on a projected canopy basis (PCA-LAI). Extension growth of tagged upper shoots of each treatment was measured every one to two months.

Relative growth rates $(R G R)$ were calculated using the standard formula

$$
R G R=\frac{\ln W_{2}-\ln W_{1}}{t_{2}-t_{1}},
$$

where $W_{1}$ and $W_{2}$ are the initial and final dry biomass, respectively, and $t_{2}-t_{1}$ is the time interval. Wholeplant biomass values over the study period presented by Wildy et al. (2002) were used for coppice and sapling treatments. Biomass of mature trees was not measured directly. Instead, increases in stem crosssectional area at $10 \%$ of plant height were used, with saplings also assessed on this basis for comparison.

A series of spot measurements of predawn leaf water potentials was taken on six mornings in NovemberDecember 2000. In total, 36 shoots detached from outer canopies of randomly selected trees of each treatment were placed inside a Scholander pressure chamber (Scholander et al., 1965), providing an indication of relative levels of water availability at this time (Ritchie and Hinckley, 1975). 


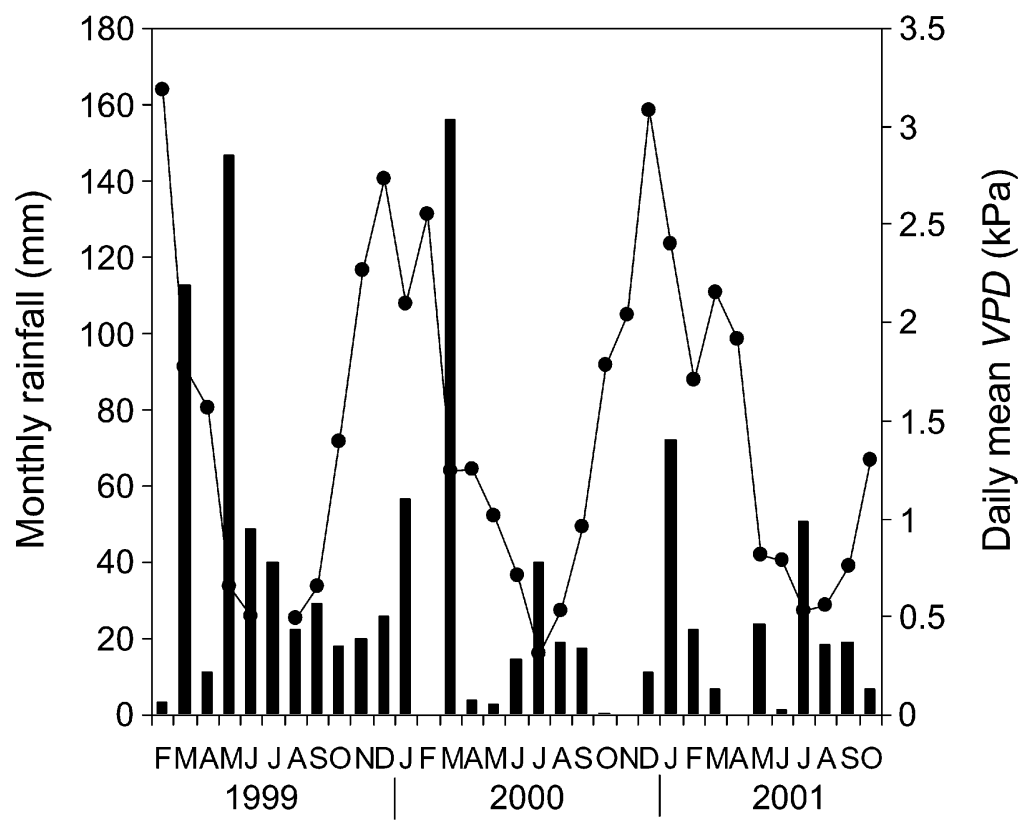

Figure 1. Rainfall (bars) at the trial site near Kalannie, Western Australia, and vapour pressure deficit during daylight hours (VPD; circles) at the nearby townsite. Data were provided by the Department of Agriculture.

Table 1. Treatment descriptions, leaf area index on projected canopy area basis (PCA-LAI) and relative growth rate (RGR) for Eucalyptus kochii subsp. plenissima growing under contrasting conditions at Kalannie, Western Australia

\begin{tabular}{|c|c|c|c|c|c|c|c|c|}
\hline & Treatment & Site & $\begin{array}{l}\text { Age of stems } \\
\text { during study } \\
\text { (yr) }\end{array}$ & $\begin{array}{l}\text { Tree height at } \\
\text { end of study } \pm \\
\text { one std. dev. } \\
\text { (m) }\end{array}$ & $\begin{array}{l}\text { Leaf wt. } \\
\text { end of } \\
\text { study } \\
\left(\mathrm{kg} \mathrm{DM} \text { tree }^{-1}\right)\end{array}$ & $\begin{array}{l}P C A-L A I \\
\text { end of } \\
\text { study }\end{array}$ & $\begin{array}{l}R G R \text { of } \\
\text { dry } \\
\text { matter } \\
\left(\times 10^{3} \mathrm{~d}^{-1}\right)\end{array}$ & $\begin{array}{l}R G R \text { of stem } \\
\text { cross-sectional } \\
\text { area } \\
\left(\times 10^{3} \mathrm{~d}^{-1}\right)\end{array}$ \\
\hline & $\begin{array}{l}\text { Mature } \\
\text { inner-bush } \\
(\mathrm{MB})\end{array}$ & $\begin{array}{l}\text { Remnant } \\
\text { vegetation }\end{array}$ & $\sim 50$ & $4.9 \pm 0.9$ & 9.0 & 1.2 & n.d. & 0.10 \\
\hline & $\begin{array}{l}\text { Mature edge } \\
\text { (ME) }\end{array}$ & $\begin{array}{l}\text { Remnant } \\
\text { vegetation on } \\
\text { paddock edge }\end{array}$ & $\sim 50$ & $7.2 \pm 0.3$ & 33.1 & 1.6 & n.d. & 0.11 \\
\hline & $\begin{array}{l}\text { Uncut } \\
\text { saplings } \\
(\mathrm{S})\end{array}$ & $\begin{array}{l}\text { Tree belts } \\
\text { through } \\
\text { paddock }\end{array}$ & $4.6-7.2$ & $2.8 \pm 0.5$ & 7.1 & 3.2 & 1.15 & 1.19 \\
\hline Q & $\begin{array}{l}\text { Coppice, cut } \\
\text { in Feb. } 1999 \\
(\mathrm{CF})\end{array}$ & $\begin{array}{l}\text { Tree belts } \\
\text { through } \\
\text { paddock }\end{array}$ & $0-2.7$ & $1.4 \pm 0.3$ & 3.3 & 2.0 & 1.23 & n.a. \\
\hline (1) & $\begin{array}{l}\text { Coppice, cut } \\
\text { in Oct. } 1999 \\
(\mathrm{CO})\end{array}$ & $\begin{array}{l}\text { Tree belts } \\
\text { through } \\
\text { paddock }\end{array}$ & $0-2.0$ & $1.7 \pm 0.3$ & 3.7 & 2.3 & 1.44 & n.a. \\
\hline
\end{tabular}

n.d.- not determined, n.a.- not applicable 


\section{Foliar characteristics}

At four dates during the study, 30 leaves were selected at random from canopies of the five treatments and halved along their midribs. One half leaf was immediately suspended in $95 \%$ alcohol containing $0.5 \mu \mathrm{g} \mathrm{L}^{-1}$ sodium ascorbate for chlorophyll extraction (Lichtenthaler, 1987) while the other half was traced for later measurement of leaf area before being dried and weighed. These latter portions were then ground and analysed for nitrogen and carbon concentration on a $\mathrm{C} \mathrm{H} \mathrm{N}$ analyser/mass spectrometer (IRMS with Roboprep, PDZ Europa, Cheshire, UK), thus allowing calculation of specific leaf area (SLA), and leaf chlorophyll and $\mathrm{N}$ contents on a foliage area basis. One-sided stomatal density of leaves was assessed by microscopy on four occasions during the study after peeling a layer of clear lacquer applied to leaf surfaces.

Since E. kochii trees retain leaves for approximately three years after their formation, canopies of mature trees and saplings were, on average, comprised of older leaves than coppice treatments. However, no important differences in age-related effects were found in an age series study of leaves of each treatment so leaf age effects were not further considered in interpretation of data.

\section{Leaf gas exchange and $\mathrm{WUE}_{\mathrm{i}}$}

Leaf gas exchange was measured every one to two months using a broad-leaf cuvette attached to an infra-red gas analyser (LCA4, Analytical Development Company, Hoddesdon, Herts, U.K.). Series of 15 measurements were made at each of four randomly selected quadrats for saplings and coppices and on each of the mature inner-bush and edge trees. Measurements were spread over two to three days, with both cloudy and sunny periods included in sampling programmes. The time of measurement was between 0900 and $1600 \mathrm{~h}$ for the longer summer days and between 1000 and $1500 \mathrm{~h}$ during winter, with morning, midday and afternoon measurements spread evenly across treatments. Measurements were conducted on leaves selected at random through the tree canopies, with the cuvette attached in the natural orientation of each leaf. Data provided were incident photosynthetically active radiation $(P A R)$, stomatal conductance $\left(g_{s}\right)$, partial pressure of $\mathrm{CO}_{2}$ in substomatal cavities $\left(p_{i}\right)$ and rates of photosynthesis $(A)$ and leaf transpiration $\left(T_{L}\right)$. Leaf level water-use efficiencies $\left(W U E_{i}\right)$ were calculated in this study as $A / T_{L}$, in the sense of Farquhar et al. (1989a, 1982).
Data for each treatment were combined to plot general time courses of changes in various measures as two- to four-monthly averages. Consistent seasonal differences then became evident between treatments so physiological parameters were then compared between treatments after segregating data for 'summer', (November-April) or 'winter' (MayOctober) periods of study. In a further analysis, all fully-expanded leaves receiving photosyntheticallysaturating $P A R$ levels ( $>1800 \mathrm{~mol} \mathrm{~m}^{-2} \mathrm{~s}^{-1}$ ) at the time of measurement were extracted from the data set and the resulting means compared to determine the extent of differences between treatments where self shading effects of canopies were not an issue.

\section{$\delta^{13} C$ of new shoot tips and below-ground starch reserves}

When upper branches were actively growing new foliage, the uppermost $3 \mathrm{~cm}$ of recently produced soft leaf and stem tissue (hereafter defined as 'shoot tips') were collected on a one- to two-month basis from the mature inner-bush and mature edge study trees and from each of the 16 replicates of coppice and sapling treatments. Shoot tip samples were oven dried to $70{ }^{\circ} \mathrm{C}$, ground and analysed for $\delta^{13} \mathrm{C}$ using the mass spectrometer detailed above for use as additional measures of water stress and water-use efficiency of treatments (Farquhar et al., 1989a).

For saplings and coppices, carbon stable isotope ratios were measured for starch extracted from belowground biomass tissues collected from ten randomly selected trees just prior to decapitation events (February 1999 and October 1999) and again just prior to the second main shoot growth period in August 2000. Selected trees were excavated to a depth of $1 \mathrm{~m}$ and lignotubers, lateral roots and tap roots sifted from the soil. Fresh samples were frozen immediately and then oven dried and ground in preparation for starch extraction. Starch analysis followed the perchloric acid extraction procedure described by Pucher et al. (1948) until solubilized starch was precipitated as a starch-iodine complex. Resulting pellets were then suspended successively in $2.5 \mathrm{~mL}$ alcoholic $\mathrm{NaCl}$, $2 \mathrm{~mL}$ alcoholic $\mathrm{NaOH}$, and then again in $2.5 \mathrm{~mL}$ alcoholic $\mathrm{NaCl}$, with centrifugation and decanting between each rinsing. The purified starch pellets were then recovered, dried and analysed for $\delta^{13} \mathrm{C}$.

Further study of the possible contribution of remobilized root starch to newly expanding shoot dry matter was conducted using shaded coppice plants, 
following preliminary findings indicating that starch carried a considerably less negative $\delta^{13} \mathrm{C}$ value than general plant dry matter. By contrast, current photosynthates produced by shaded plants under low light intensity would be expected to show extremely negative $\delta^{13} \mathrm{C}$ signatures (Farquhar et al., 1989a). In each of the 16 replicates of February and October-cut coppices, three trees were enclosed immediately after decapitation within cages of multiple shade cloth permitting entry of approximately $25 \%$ of ambient light. Recently expanded new shoot tips were collected at one- to two-monthly intervals and analysed for $\delta^{13} \mathrm{C}$. One flagged stem of each plant was monitored at each sampling date to follow seasonal progress of shoot growth and determine when new growth had ceased.

\section{Water-use efficiency at whole-plant level (WUE ${ }_{\mathrm{DM}}$ and $\mathrm{WUE}_{\mathrm{XS}}$ )}

Water-use efficiency at whole-plant level was measured either as the ratio of whole-plant dry matter produced per unit water transpired $\left(W U E_{D M}\right)$ or using increases in stem cross-sectional area as an index of dry matter production, to give $W U E_{X S}$ (Honeysett et al., 1992; Köstner et al., 2002; Olbrich et al., 1993). $W U E_{D M}$ was calculated for saplings and October 1999-cut coppice over the period November 1999 to October 2001 using data for increases in dry matter of shoots, lignotubers and roots from the study of Wildy and Pate (2002) and transpiration data presented in Wildy et al. (in press). For the latter, data for three separate locations across the study area (Sites 1 , 2 and 3 of Wildy et al., in press) were combined to represent the average condition of the tree belts across the paddock.

Water use of selected stems of mature trees was measured using the heat pulse method (Hatton et al., 1995), employing Greenspan (Warwick, Qld., Australia) SF300 split probe sensors. Eight stems (two for each of four trees) were logged at any one time (two probe sets per stem) for both mature inner-bush and edge treatments. Installations were changed every six to nine months into a new set of stems. At the end of the study period, logged stems were felled below sites of installation of the probes and sapwood area (measured progressively via core samples) determined definitively by inspecting the extent of peripheral wet wood clearly visible in transverse sections of the stems. Data for transpiration and stem cross-sectional area increases of saplings were taken from the data set of Wildy et al. (in press). $W U E_{X S}$ was then estimated for each installation period as the quotient of the increase in cross sectional area at $10 \%$ of stem height and total transpiration.

\section{Statistical analyses}

The statistical program, MINITAB, was used for performing one-way ANOVA with Tukey's test for significant differences between means. Regression analysis was used to show relationships between measured parameter means.

\section{Results}

Growth rates, foliar characteristics and leaf water potentials of treatments

Mature (> 50-year-old) E. kochii stems of inner-bush showed significantly lower $(P<0.05)$ basal diameters $(9.2 \mathrm{~cm})$ and leaf biomass $\left(9 \mathrm{~kg} \mathrm{DM}\right.$ tree $^{-1}$, Table 1) than similarly aged edge trees growing adjacent to the cleared paddock $(16.9 \mathrm{~cm}$ and $33 \mathrm{~kg}$, respectively). Leaf area index on a projected canopy basis (PCA-LAI) of mature inner-bush (1.2) was also less than for mature edge trees (1.6). Seven-year-old belt-planted saplings had achieved a mean basal stem diameter of $6.6 \mathrm{~cm}$, leaf biomass of $7.1 \mathrm{~kg} \mathrm{DM}$ tree $^{-1}$ and PCA-LAI of 3.2 by the end of the study (Table 1 ). Coppices of similar rootstock age showed a mean final leaf biomass of $3.3-3.7 \mathrm{~kg} \mathrm{DM}$ tree $^{-1}$, and a PCA-LAI progressing from zero at the time of decapitation to $2.0-2.3$ by the end of the study.

Mean pre-dawn leaf water potentials measured in late 2000 were significantly lower $(P<0.01)$ for mature inner-bush trees $(-2.59 \mathrm{MPa})$ than mature edge trees $(-1.90 \mathrm{MPa})$ and in turn significantly lower $(P<0.01)$ than saplings $(-0.86 \mathrm{MPa})$, Februarycut coppice $(-0.79 \mathrm{MPa})$ and October-cut coppice $(-0.67 \mathrm{MPa})$.

Relative growth rates were determined for saplings and coppices on a plant dry matter basis and indirectly for bush trees in terms of increases in stem crosssectional area (Table 1). Where both methods were applied to uncut saplings similar values resulted, namely 1.15 and $1.19 \times 10^{-3} \mathrm{day}^{-1}$, respectively. Both coppice treatments showed higher relative growth rates than uncut saplings, and values for all alley-planted trees were an order of magnitude greater than those of mature bush trees $\left(\sim 0.1 \times 10^{-3} \mathrm{day}^{-1}\right.$, Table 1$)$.

Shoot extension of mature inner-bush and edge trees occurred slowly over a five month period fol- 


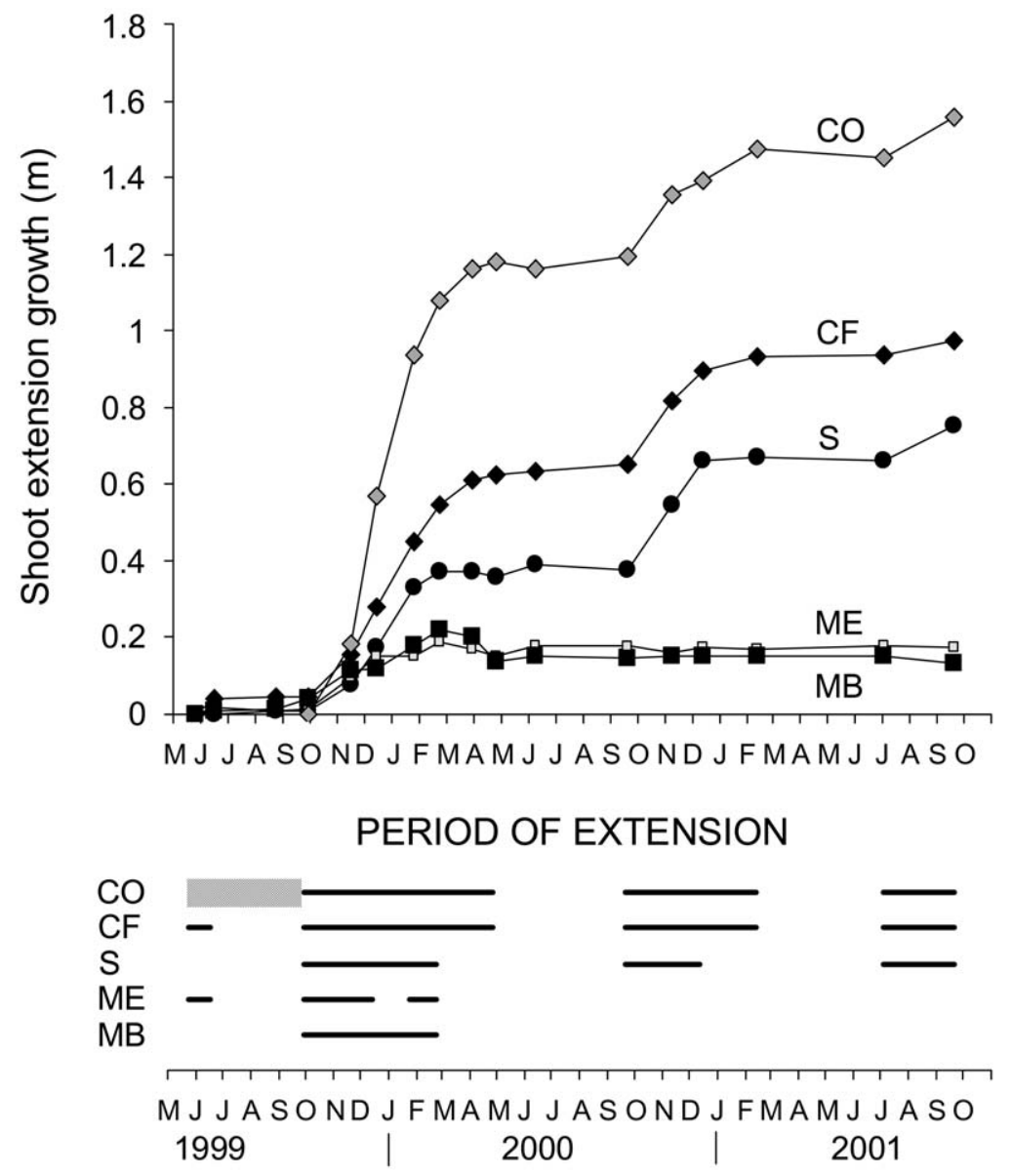

Figure 2. Profiles of extension growth of leading shoots of Eucalyptus kochii subsp. plenissima at Kalannie, Western Australia, growing as mature trees within remnant bush (MB), edging cleared agricultural land (ME), or growing in belts through agricultural land as saplings (S) or coppices regenerating from cuts in February 1999 (CF) or October 1999 (CO).

lowing large rain events at the beginning of the study but virtually ceased thereafter (Figure 2). Saplings extended their shoots over a four month period during spring and summer each year while coppices showed a growing period of up to seven months per year. Coppice shoot extension also occurred at a considerably faster rate than in intact trees of other treatments (Figure 2).

Leaves of young coppice canopies had significantly higher $(P<0.05)$ specific leaf areas $\left(24 \mathrm{~cm}^{-2} \mathrm{~g}^{-1}\right)$ than saplings or mature trees (19$22 \mathrm{~cm}^{-2} \mathrm{~s}^{-1}$ ) (Table 2) associated with a reduced laminar thickness. Leaves of mature edge trees were significantly more enriched in chlorophyll per unit leaf dry matter $(P<0.05)$ than other treatments. Chlorophyll concentrations per unit leaf area, then, were highest for mature edge trees $\left(80 \mu \mathrm{g} \mathrm{cm}^{-2}\right)$ and least for coppice treatments $\left(61-64 \mu \mathrm{g} \mathrm{cm}^{-2}\right)$. Leaf nitro- gen levels per unit leaf area displayed similar trends to leaf chlorophyll. There were no consistent patterns in stomatal density between leaves of the five treatments (Table 2).

\section{Leaf gas exchange averaged over whole canopies}

Mean incident illumination levels were lower for sapling canopies of high PCA-LAI than for young coppices or sparse mature inner-bush trees (Figure $3 \mathrm{~A}$ ). There were large and consistent differences in mean $g_{s}$ between treatments (Figure 3B), with coppices showing significantly greater values $(P<0.05)$ than other treatments in seven of the twelve sampling dates. In contrast, mature inner-bush trees showed consistently lowest $g_{s}$ values, whether after heavy summer rains early in the study period $\left(0.20 \mathrm{~mol} \mathrm{~m}^{-2} \mathrm{~s}^{-1}\right)$ or towards the much drier latter part of the study period 
Table 2. Foliar characteristics of fully-expanded leaves of Eucalyptus kochii subsp. plenissima averaged over the 2.7 year study period at Kalannie, Western Australia. Means subtended by common letters are not significantly different $(\alpha=0.05)$

\begin{tabular}{llllll}
\hline Treatment & $\begin{array}{l}\text { Specific leaf area } \\
\left(\mathrm{cm}^{2} \mathrm{~g}^{-1}\right)\end{array}$ & \multicolumn{2}{c}{$\begin{array}{l}\text { Leaf chlorophyll } \\
\left(\mathrm{mg} \mathrm{g}^{-1}\right)\end{array}$} & $\begin{array}{l}\text { Leaf N } \\
\left(\mu \mathrm{g} \mathrm{cm}^{-2}\right)\end{array}$ & $\begin{array}{l}\text { Stomatal density } \\
\left(\mu \mathrm{g} \mathrm{cm}^{-2}\right)\end{array}$ \\
\hline Mature inner-bush & $22.2 \mathrm{~b}$ & $1.46 \mathrm{ab}$ & $69.5 \mathrm{a}$ & $536 \mathrm{a}$ & $122 \mathrm{ab}$ \\
Mature edge & $20.3 \mathrm{a}$ & $1.62 \mathrm{~b}$ & $79.9 \mathrm{~b}$ & $601 \mathrm{~b}$ & $98 \mathrm{a}$ \\
Saplings & $19.3 \mathrm{a}$ & $1.30 \mathrm{a}$ & $68.3 \mathrm{a}$ & $541 \mathrm{a}$ & $112 \mathrm{ab}$ \\
Coppice (Feb.-cut) & $23.9 \mathrm{c}$ & $1.42 \mathrm{a}$ & $61.2 \mathrm{a}$ & $530 \mathrm{a}$ & $101 \mathrm{a}$ \\
Coppice (Oct.-cut) & $24.3 \mathrm{c}$ & $1.47 \mathrm{ab}$ & $64.0 \mathrm{a}$ & $512 \mathrm{a}$ & $122 \mathrm{~b}$ \\
\hline
\end{tabular}

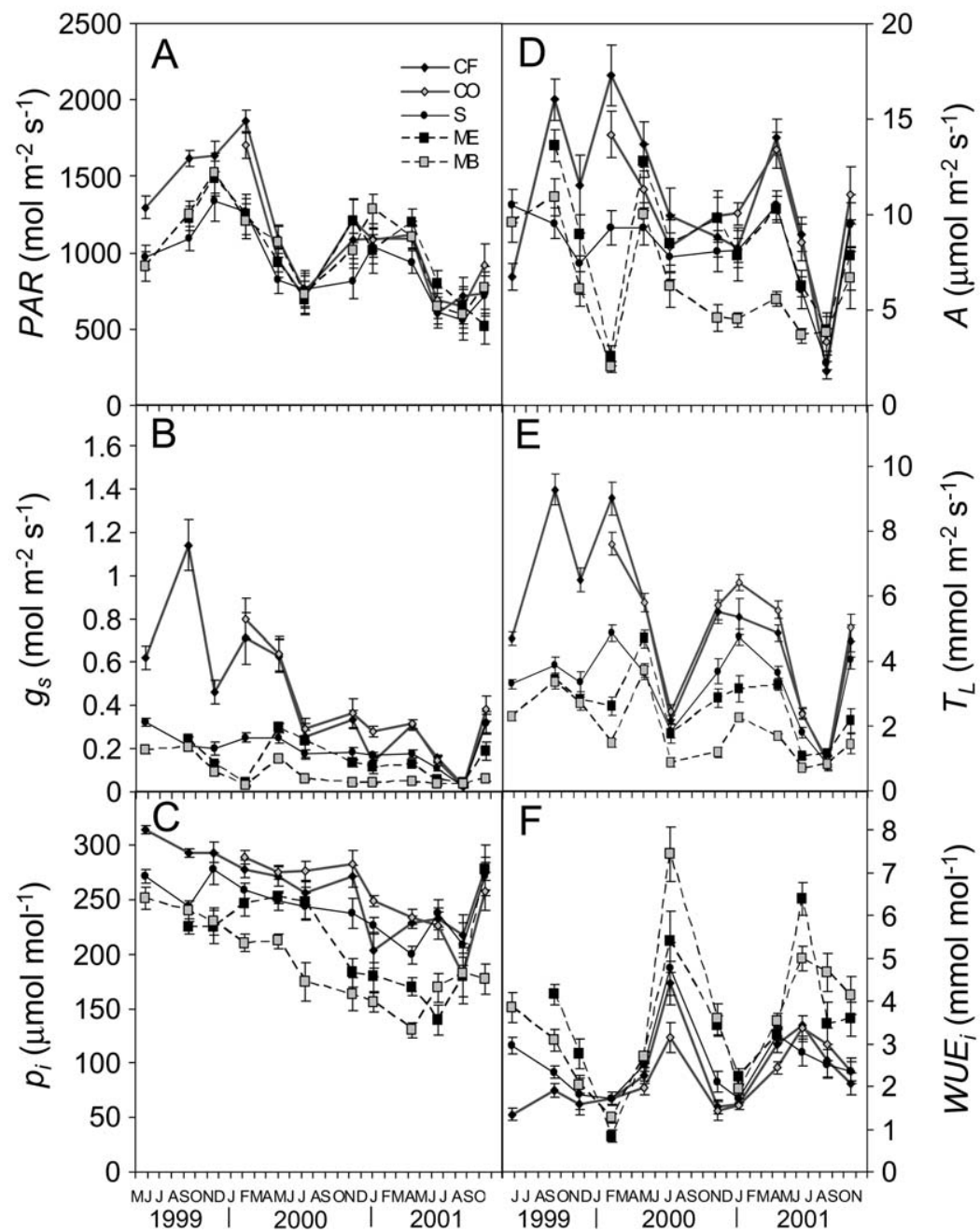

Figure 3. Gas exchange characteristics of Eucalyptus kochii subsp. plenissima at Kalannie, Western Australia, growing as mature trees within remnant bush (MB), edging cleared agricultural land (ME), or growing in belts through agricultural land as saplings (S) or coppices regenerating from cuts in February 1999 (CF) or October 1999 (CO). Data represent averages for leaves sampled at random through canopies at mean illumination levels (A); (B) stomatal conductance; (C) substomatal $\mathrm{CO}_{2}$ concentration; (D) photosynthetic rate; (E) leaf transpiration rate; (F) intrinsic water-use efficiency calculated as $A / T_{L}$. Bars indicate \pm one standard error. 
(0.03 mol m $\left.\mathrm{m}^{-2} \mathrm{~s}^{-1}\right)$. Substomatal $\mathrm{CO}_{2}$ concentrations $\left(p_{i}\right)$ (Figure 3C) were ranked similarly to $g_{s}$, indicating a more effective absorption of available $\mathrm{CO}_{2}$ by mature inner-bush trees than by other canopy types. Foliar $p_{i}$ decreased progressively in mature inner-bush and edge trees, again consistent with increasing water stress in the drier second half of the study period for these treatments.

Coppice canopies almost always photosynthesised at greater rates than those of other treatments, whereas lowest $A$ values were mostly encountered by mature inner-bush trees (Figure 3D). Leaf transpiration rates strongly reflected $g_{s}$, but with an overlying trend for higher rates in hot summer months of high VPD (Figure 3E and Figure 1). Water-use efficiency of photosynthetic carbon gain $\left(W U E_{i}\right.$, calculated as $A / T_{L}$, Figure $3 \mathrm{~F}$ ) was accordingly higher in winter months of low VPD. Mature trees showed greatest $W U E_{i}$ in all but the hottest months (January-February) when all treatments fell to similarly low values. Coppice foliage was generally least water efficient in terms of carbon fixation, especially in the first year after cutting.

Regressions of gas exchange data for foliage averaged over whole canopies (Figure 4) indicated a strong relationship between $g_{s}$ and $p_{i}$ regardless of treatment and season (Figure 4A; $r^{2}=0.89$ ), and paralleled by concurrent increases in $A$ (Figure $4 \mathrm{~B} ; r^{2}=0.74$ ). However, high $p_{i}$ of coppices failed to relate to linearly high increases in $A$ (cf. Figures $4 \mathrm{~A}$ and B). Leaf transpiration (Figure $4 C$ ) and $W U E_{i}$ (Figure 4D) were similarly strongly dependent on $g_{s}$, albeit with summer values differentiated from those of winter due to the differences in ambient VPD. Low $g_{s}$ by mature inner-bush canopies resulted in low $A$ but high $W U E_{i}$, whereas high $g_{s}$ of coppice canopies lead to high values for $A$ with low $W U E_{i}$.

\section{Leaf gas exchange at saturating light intensities}

Marked differences in $g_{s}$ between treatments were particularly apparent for foliage functioning under saturating light intensities, with means ranging from $0.12 \mathrm{~mol} \mathrm{~m}^{-2} \mathrm{~s}^{-1}$ for mature inner-bush trees to $0.83 \mathrm{~mol} \mathrm{~m}^{-2} \mathrm{~s}^{-1}$ for first-year February-cut coppice (Table 3 ). Values for $T_{L}$ more or less mirrored the same pattern, with mature inner-bush trees significantly lower than all but mature edge trees, followed in turn by uncut saplings, second-year coppices and then by the very fast-transpiring first-year coppices. Despite these differences in $g_{s}$, only mature inner-bush trees showed significantly lower rates of photosynthesis $\left(10 \mu \mathrm{mol} \mathrm{m} \mathrm{m}^{-2} \mathrm{~s}^{-1}\right)$ than other treatments (range 15-17 $\mu \mathrm{mol} \mathrm{m} \mathrm{m}^{-2} \mathrm{~s}^{-1}$ ). Differences in $W U E_{i}$ encompassed a two-fold range, namely from $1.9 \mathrm{mmol} \mathrm{mol}^{-1}$ for first year February-cut coppice to $4.0 \mathrm{mmol} \mathrm{mol}^{-1}$ for mature edge trees. These differences were inversely related to $p_{i}$ values recorded across treatments (Table 3).

\section{$\delta^{13}$ C of new shoot tips and below-ground starch reserves}

Differences in shoot tip $\delta^{13} \mathrm{C}$ between treatments (see Figure 5A) were complicated by the much shorter period of shoot extension shown by mature bush than by young alley-planted trees. However, on those occasions when all treatments were producing new shoot tips, mean values for mature inner-bush and mature edge trees $(-22.7$ and $-23.8 \%$, respectively) proved to be significantly $(P<0.05)$ less negative than that of saplings $(-24.9 \%)$, which were in turn significantly less negative than those of October-cut coppice $(-25.5 \%)$ and February-cut coppice $(-26.1 \% 0)$. Time courses of shoot tip $\delta^{13} \mathrm{C}$ of coppices (Figure 5A) indicated that each seasonal flush of growth was first produced with dry matter $\delta^{13} \mathrm{C}$ at around $-24 \%$ which then decreased to -26 to $-28 \%$ before increasing towards the end of the flush of new growth.

Starch extracted from roots and lignotubers of trees just prior to decapitation of the coppice treatments carried $\delta{ }^{13} \mathrm{C}$ signatures of $-23.2 \%$ and $-23.6 \%$ for the February- and October-cut trees, respectively. In August 2000 just prior to the new spring shoot flush, roots of coppices and saplings both contained starch with a similar value (mean $\delta^{13} \mathrm{C}$ of $-23.8 \%$ ). New shoot tips thus showed $\delta^{13} \mathrm{C}$ signatures very similar to those of root starch at the beginning of all growth flushes, but then later became significantly more negative (Figure 5A). During the 12-15 months following decapitation when shaded trees produced new shoot tips, the general trend was again for earliest-formed shoots to possess $\delta^{13} \mathrm{C}$ signatures $(-23$ to $-24 \%$ ) close to that of starch $(-23.2$ to $-23.6 \%)$ after which they decreased significantly $(P<0.05)$ to the range of -26 to $-28 \%$ (Figure $5 \mathrm{~B}$ ).

\section{Relationships between shoot tip $\delta^{13} C, \mathrm{p}_{\mathrm{i}}, \mathrm{WUE}_{\mathrm{i}}$ and leaf photosynthetic capacity}

Although carbon of stored starch appeared to be involved in the early growth of each new flush of shoots produced by coppices and saplings, a strong positive 

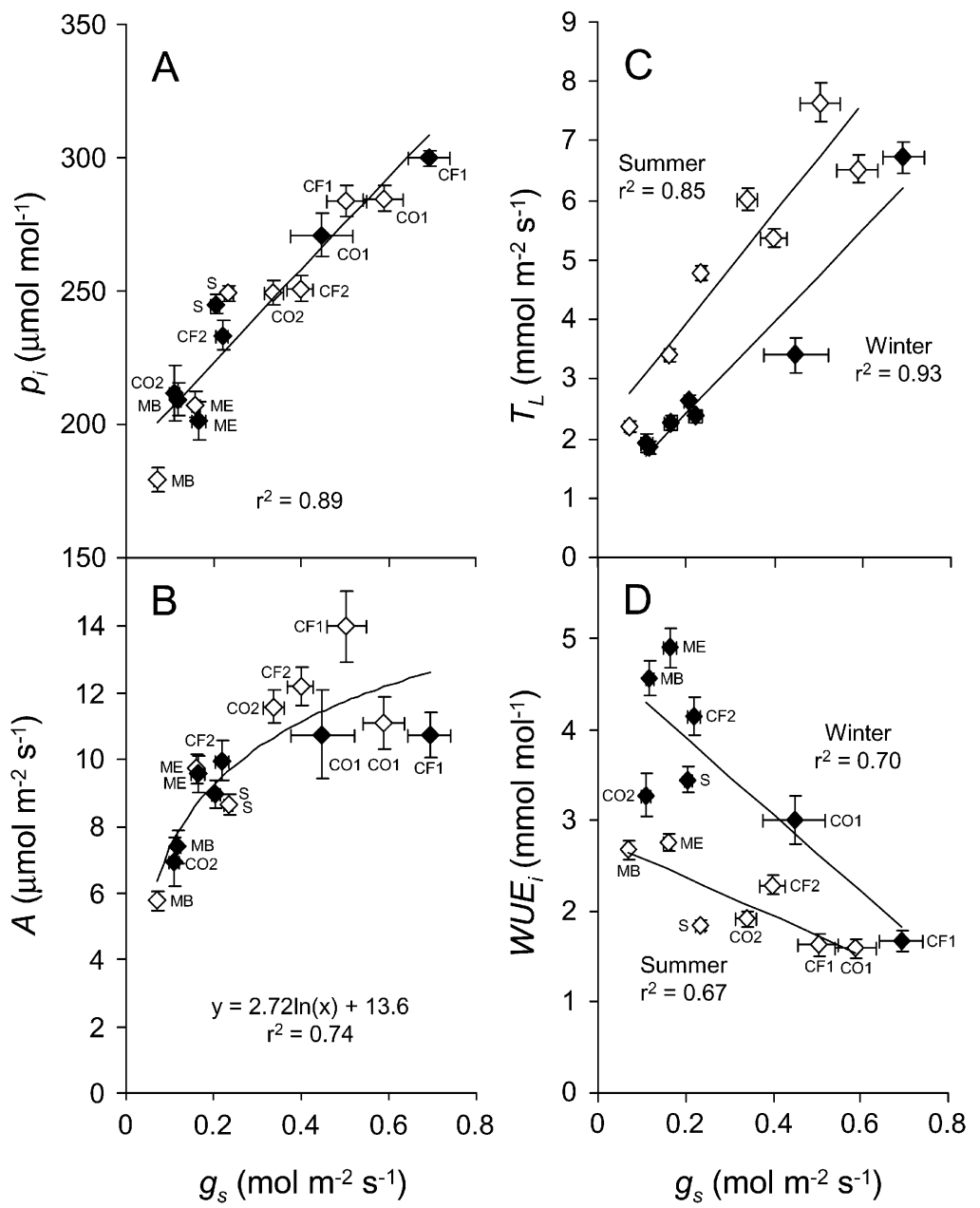

Figure 4. Correlations between stomatal conductance and other attributes of foliar performance averaged over whole canopies of Eucalyptus kochii subsp. plenissima at Kalannie, Western Australia. Data are means for summer months (open symbols) or winter months (closed symbols) for each treatment: $\mathrm{MB}$, mature trees within remnant bush; ME, mature trees on edge bordering cleared land; S, CF \& CO, trees belt-planted through paddocks either left as uncut saplings, or coppiced in February 1999 or in October 1999, respectively. Data for coppices are presented separately for the first and subsequent years after decapitation, denoted 1 and 2, respectively. Bars indicate \pm one standard error.

Table 3. Mean leaf gas exchange parameters for fully-expanded leaves exposed to saturating light intensity for Eucalyptus kochii subsp. plenissima at Kalannie, Western Australia. Means subtended by common letters are not significantly different $(\alpha=0.05)$

\begin{tabular}{llllll}
\hline & $\begin{array}{l}g_{s} \\
\left(\mathrm{~mol} \mathrm{~m}^{-2} \mathrm{~s}^{-1}\right)\end{array}$ & $\begin{array}{l}T_{L} \\
\left(\mathrm{mmol} \mathrm{m}^{-2} \mathrm{~s}^{-1}\right)\end{array}$ & $\begin{array}{l}A \\
\left(\mu \mathrm{mol} \mathrm{m}^{-2} \mathrm{~s}^{-1}\right)\end{array}$ & $\begin{array}{l}W U E_{i} \\
\left(\mathrm{mmol} \mathrm{mol}^{-1}\right)\end{array}$ & $\begin{array}{l}p_{i} \\
\left(\mu \mathrm{mol} \mathrm{mol}^{-1}\right)\end{array}$ \\
\hline $\begin{array}{l}\text { Mature inner-bush } \\
\text { Mature edge }\end{array}$ & $0.12 \mathrm{a}$ & $3.1 \mathrm{a}$ & $10.0 \mathrm{a}$ & $3.4 \mathrm{bc}$ & $159 \mathrm{a}$ \\
$\begin{array}{l}\text { Saplings } \\
\text { Coppice (Feb.-cut })\end{array}$ & $0.20 \mathrm{ab}$ & $4.2 \mathrm{ab}$ & $15.5 \mathrm{~b}$ & $4.0 \mathrm{c}$ & $168 \mathrm{ab}$ \\
$\quad$ & $5.3 \mathrm{c}$ & $15.2 \mathrm{~b}$ & $3.3 \mathrm{bc}$ & $208 \mathrm{c}$ \\
$\quad 1^{\text {st }}$ year & $0.83 \mathrm{~d}$ & $8.4 \mathrm{e}$ & $16.0 \mathrm{~b}$ & $1.9 \mathrm{a}$ & $280 \mathrm{e}$ \\
$2^{\text {nd }}$ year & $0.33 \mathrm{bc}$ & $5.5 \mathrm{bcd}$ & $16.5 \mathrm{~b}$ & $3.4 \mathrm{bc}$ & $206 \mathrm{~cd}$ \\
$\begin{array}{c}\text { Coppice (Oct.-cut }) \\
\quad 1^{\text {st }} \text { year }\end{array}$ & $0.54 \mathrm{c}$ & $7.1 \mathrm{de}$ & $17.2 \mathrm{~b}$ & $2.5 \mathrm{ab}$ & $240 \mathrm{~d}$ \\
$2^{\text {nd }}$ year & $0.26 \mathrm{ab}$ & $6.4 \mathrm{~cd}$ & $15.5 \mathrm{~b}$ & $2.8 \mathrm{ab}$ & $194 \mathrm{bc}$ \\
\hline
\end{tabular}


correlation was still evident between mean $p_{i}$ of lightsaturated fully-expanded leaves and the $\delta^{13} \mathrm{C}$ signature of new shoot tips (Figure $6 \mathrm{~A} ; r^{2}=0.79$ ). On average, differences in shoot tip $\delta^{13} \mathrm{C}$ values between summer and winter months were small (Figure 6B), but owing to the effect of $V P D$ on $W U E_{i}$, a given $\delta^{13} \mathrm{C}$ signature in winter months was associated with better $W U E_{i}$ than in summer months for all treatments (Figure 6B). This finding was fully consistent with predictions from the formulae of Farquhar et al. (1982) relating $W U E_{i}$ to $\delta^{13} \mathrm{C}$ via variations in $V P D$ and $p_{i}$. There were strong relationships between leaf chlorophyll concentration and $W U E_{i}$ of light-saturated leaves (Figure 6C), and chlorophyll levels were higher in winter months. Relationships with leaf $\mathrm{N}$ content on an area basis followed similar patterns as chlorophyll but correlations were less strong (Figure 6D).

\section{Water-use efficiency of whole-plant growth (WUE ${ }_{\mathrm{DM}}$ and $\mathrm{WUE}_{\mathrm{XS}}$ )}

Using estimates of above- and below-ground biomass and whole-tree transpiration provided for alley treatments by Wildy and Pate (2002) and Wildy et al. (in press), uncut saplings were found to produce only $24 \%$ more shoot biomass but twice the amount of root biomass as did October-cut coppice (Table 4). Then with transpiration of uncut saplings twice that of coppice, water-use efficiency in dry matter production $\left(W U E_{D M}\right)$ of the former was $1.8 \mathrm{~g} \mathrm{DM} \mathrm{L}^{-1}$ compared to a significantly higher $(P<0.05)$ value of $2.3 \mathrm{~g} \mathrm{DM} \mathrm{L}^{-1}$ for coppice (Table 4 ).

Water-use efficiency was also assessed as stem transpiration versus increases in stem-cross-sectional area $\left(W U E_{X S}\right.$; Table 5) for non-coppiced treatments. Transpiration rates were greatest for large mature edge trees but since their increases in cross-sectional area were small, low values for $W U E_{X S}$ were evident $\left(0.1 \mathrm{~mm}^{2} \mathrm{~L}^{-1}\right)$. Stems of inner-bush trees transpired slowly and showed extremely low rates of increase in cross-sectional area, and their $W U E_{X S}$ was also low $\left(0.2 \mathrm{~mm}^{2} \mathrm{~L}^{-1}\right)$. By contrast, high transpiration of sapling coupled to fast rates of stem growth resulted in high $W U E_{X S}\left(0.7 \mathrm{~mm}^{2} \mathrm{~L}^{-1}\right)$.

\section{Comparisons of different measures of water-use efficiency}

Based on leaf-level assays of $A$ and $T_{L}$, mean wateruse efficiencies over whole canopies were similar for October-cut coppice (1.60 $\mathrm{g} \mathrm{C} \mathrm{L}^{-1}$ ) and saplings (1.75 $\mathrm{g} \mathrm{C} \mathrm{L}^{-1}$, Table 6). However, when compared in terms of whole-plant gain in carbon per unit of transpiration, coppiced trees were significantly $(P<$ $0.05)$ more water-use efficient $\left(1.16 \mathrm{~g} \mathrm{C} \mathrm{L}^{-1}\right)$ than saplings $\left(0.88 \mathrm{~g} \mathrm{C} \mathrm{L}^{-1}\right)$. Mature inner-bush and edge trees showed much lower water-use efficiency than saplings in production of stem cross-sectional area (Table 6). By inference, coppiced trees would also have been far more water-use efficient than mature trees on a whole-plant basis.

\section{Discussion}

With mature natural bush and alley-planted agricultural land both containing E. kochii trees, the site at Kalannie provided a useful situation for assessing the inherent variation in growth and water-use efficiency of a mallee species. Water availability differed between treatments as indicated by spot measurements of predawn leaf water potentials, and the $3 \%$ differences in mean $\delta^{13} \mathrm{C}$ values of new shoot growth provided evidence of lower water stress in paddockgrown trees than mature inner-bush and edge trees. Our companion studies of water use also demonstrated greater soil moisture resources available to the tree belts through agricultural land (Wildy et al., in press) than in natural bush at a site close to that of the present study (see Mappin et al., 2003).

For paddock-grown trees, higher water availability was associated with higher stomatal conductance and lower leaf level water-use efficiency $\left(W U E_{i}\right)$ and $\delta^{13} \mathrm{C}$ than drought stressed mature bush trees. Despite this, paddock-grown trees appeared to posses much higher water-use efficiency in overall dry matter production $\left(W U E_{D M}\right.$ or $W U E_{X S}$ ) than drought stressed mature trees. In particular, coppice, with highest stomatal conductance and leaf photosynthetic rates, showed greatest $W U E_{D M}$ despite lowest $W U E_{i}$ and $\delta^{13} \mathrm{C}$. An explanation for these results is given below.

Averaged over the study period, mean canopy $g_{s}$ showed a five-fold difference between the mature inner-bush trees (lowest values) and coppiced trees (highest values), but even greater mean values were apparent in foliage of first year coppices. It is well known that $g_{s}$ of many drought-adapted tree species increases when more water is available (Ladiges, 1974; McJannet and Vertessy, 2001; Osório and Pereira, 1994; Sparks and Black, 1999; Stoneman et al., 1994) and this study indicates that $g_{s}$ of E. kochii increases yet again after trees are coppiced. This result is consistent with comparisons of saplings 
Table 4. Calculation of water-use efficiency of dry matter production (WUE $\left.{ }_{D M}\right)$ for Eucalyptus kochii subsp. plenissima as uncut saplings or October-cut coppice, calculated from biomass increase (data from Wildy and Pate, 2002) and transpiration (Wildy et al., in press) over a 22 month period at three locations across the study paddock at Kalannie, Western Australia. Means subtended by different letters are significantly different $(\alpha=0.05)$

\begin{tabular}{|c|c|c|c|c|c|}
\hline & $\begin{array}{l}\text { Above-ground growth } \\
\text { increment } \\
\left(\mathrm{kg} \mathrm{DM} \text { tree }{ }^{-1}\right)\end{array}$ & $\begin{array}{l}\text { Lignotuber growth } \\
\text { increment } \\
\left(\mathrm{kg} \mathrm{DM}^{-1} \mathrm{e}^{-1}\right)\end{array}$ & $\begin{array}{l}\text { Root growth } \\
\text { increment } \\
\left(\mathrm{kg} \mathrm{DM}_{\text {tree }}{ }^{-1}\right)\end{array}$ & $\begin{array}{l}\text { Transpiration } \\
\left(\mathrm{L} \text { tree }^{-1}\right)\end{array}$ & $\begin{array}{l}W U E_{D M} \\
\left(\mathrm{~g} \mathrm{DM} \mathrm{L}^{-1}\right)\end{array}$ \\
\hline \multicolumn{6}{|c|}{ Uncut saplings } \\
\hline Site 1 & 9.1 & 1.1 & 3.3 & 6650 & 2.03 \\
\hline Site 2 & 8.2 & 1.0 & 3.0 & 7700 & 1.58 \\
\hline Site 3 & 13.3 & 1.6 & 4.8 & 11500 & 1.71 \\
\hline Mean & 10.2 & $1.2 \mathrm{~b}$ & $3.7 \mathrm{~b}$ & $8620 \mathrm{~b}$ & $1.77 \mathrm{a}$ \\
\hline \multicolumn{6}{|c|}{ October-cut coppice } \\
\hline Site 1 & 7.5 & 0.4 & 1.4 & 3660 & 2.54 \\
\hline Site 2 & 7.5 & 0.4 & 1.4 & 4270 & 2.17 \\
\hline Site 3 & 9.8 & 0.5 & 2.6 & 5800 & 2.23 \\
\hline Mean & 8.2 & $0.5 \mathrm{a}$ & $1.8 \mathrm{a}$ & $4580 \mathrm{a}$ & $2.31 \mathrm{~b}$ \\
\hline
\end{tabular}

Table 5. Calculation of water-use efficiency on the basis of stem cross-sectional area increase (WUEXS) for Eucalyptus kochii subsp. plenissima at Kalannie, Western Australia. Means subtended by common letters are not significantly different $(\alpha=0.05)$

\begin{tabular}{|c|c|c|c|c|}
\hline & $\begin{array}{l}\text { Stem diameter at end of study } \\
(\mathrm{cm})\end{array}$ & $\begin{array}{l}\text { Daily increase in stem cross- } \\
\text { sectional area } \\
\left(\mathrm{mm}^{2} \text { day }^{-1}\right)\end{array}$ & $\begin{array}{l}\text { Daily transpiration per stem } \\
\left(\mathrm{L} \mathrm{day}^{-1}\right)\end{array}$ & $\begin{array}{l}\text { Mean } W U E_{X S} \\
\left(\mathrm{~mm}^{2} \mathrm{~L}^{-1}\right)\end{array}$ \\
\hline Mature inner-bush & $9.4 \mathrm{~b}$ & $0.6 \mathrm{a}$ & $2.4 \mathrm{~b}$ & $0.20 \mathrm{a}$ \\
\hline Mature edge & $16.9 \mathrm{c}$ & $2.6 \mathrm{ab}$ & $23.1 \mathrm{a}$ & $0.10 \mathrm{a}$ \\
\hline Saplings & $6.6 \mathrm{a}$ & $3.8 \mathrm{~b}$ & $5.2 \mathrm{a}$ & $0.69 \mathrm{~b}$ \\
\hline
\end{tabular}

and coppices of other species (Bassman and Dickman, 1982; DeSouza et al., 1986; Kruger and Reich, 1993; Tschaplinski and Blake, 1989). Higher canopy $g_{s}$ of coppices should translate into higher substomatal $\mathrm{CO}_{2}$ concentrations and hence into higher photosynthetic rates. This was indeed substantiated here for E. kochii (Figure 4).

Mean photosynthetic rates for E. kochii under full sun (15-17 $\left.\mu \mathrm{mol} \mathrm{m}^{-2} \mathrm{~s}^{-1}\right)$ are comparable with those shown by other eucalypts including faster growing forest species (Pinkard et al., 1999; Prior et al., 1997; Sefton et al., 2002; Stoneman et al., 1994). These relatively high photosynthetic rates were associated with very low SLAs and high chlorophyll contents per unit area in the species (cf. data for other woody taxa of Bennett et al., 1997; Li, 1999; Rundel et al., 1988; Specht and Rundel, 1990). Variations in these latter determinants of leaf photosynthetic capacity were significant between treatments (1.3-fold). Coppices ranked lowest, with least leaf chlorophyll concentration on an area basis due to significantly higher SLAs than other canopy types. Lower photosynthetic capacity of coppice treatments were reflected in the non-linear relationship between $g_{s}$ and $A$, with large increases in $g_{s}$ of first year coppices failing to realise equivalently large relative gains in photosynthetic rate (Figure 4). Similarly, under light-saturated conditions four-fold greater $g_{s}$ in coppices than mature edge trees only enabled the former to achieve photosynthesis rates equivalent to those of mature edge trees with higher leaf chlorophyll levels (Table 3).

Our finding of low photosynthetic capacity of coppice foliage on a unit leaf area basis is at variance with the findings of Kauppi et al. (1990) for willow (Salix) whose fast growing resprouts possessed much higher photosynthetic capacities than corresponding 


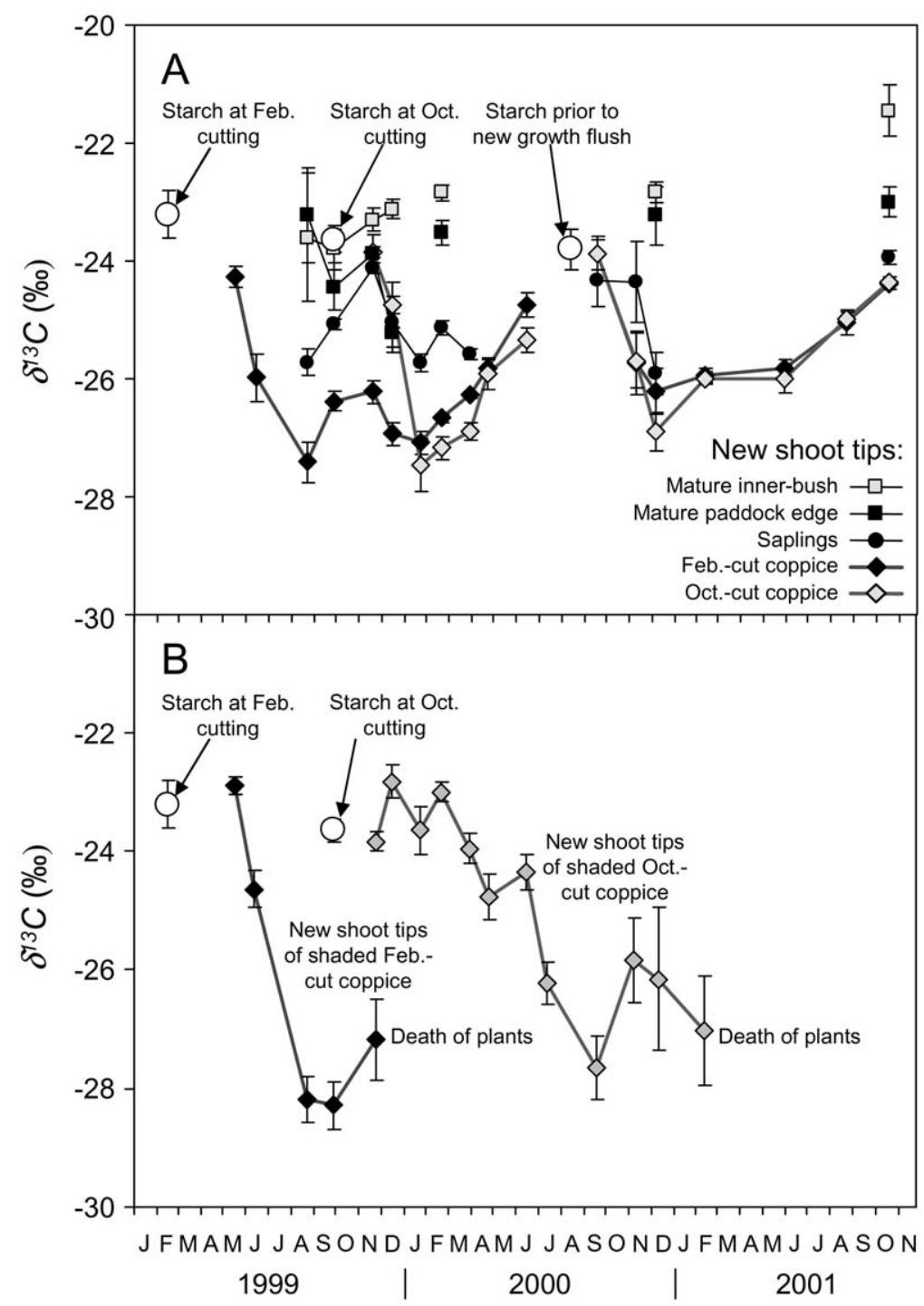

Figure 5. Carbon isotope signatures of starch extracted from bulk below-ground biomass of coppices and saplings, and for dry matter of new shoot tips of all five treatments produced sequentially across each seasonal flush of growth for Eucalyptus kochii subsp. plenissima at Kalannie, Western Australia. (A) All treatments growing naturally, (B) coppices shaded immediately after decapitation until their eventual death. Note longer duration of growth flush of saplings and coppices in cleared paddock than in trees of remnant bush. Bars indicate \pm one standard error.

Table 6. Summary of different measures of water-use efficiency for Eucalyptus kochii subsp. plenissima growing under different conditions at Kalannie, Western Australia, converted where possible to common units. Means subtended by common letters are not significantly different $(\alpha=0.05)$

\begin{tabular}{llll}
\hline & $\begin{array}{l}\text { Leaf gas exchange } \\
\left(\text { based on } W U E_{i}\right) \\
\left(\mathrm{g} \mathrm{C} \mathrm{L}^{-1}\right)\end{array}$ & $\begin{array}{l}\text { Whole-plant biomass and transpiration } \\
\left(\text { based on } W U E_{D M}\right) \\
\left(\mathrm{g} \mathrm{C} \mathrm{L}^{-1}\right)\end{array}$ & $\begin{array}{l}\text { Stem cross-sectional area and transpiration } \\
\left(W U E_{X S}\right) \\
\left(\mathrm{mm}^{2} \text { stem cross-sectional area L }\right.\end{array}$ \\
\hline Mature inner-bush & $2.35 \mathrm{~b}$ & n.d. & $0.20 \mathrm{a}$ \\
Mature edge & $2.47 \mathrm{~b}$ & n.d. & $0.10 \mathrm{a}$ \\
Saplings & $1.75 \mathrm{a}$ & $0.88 \mathrm{a}$ & $0.69 \mathrm{~b}$ \\
Coppice (October-cut) & $1.60 \mathrm{a}$ & $1.16 \mathrm{~b}$ & n.d. \\
\hline
\end{tabular}

n.d.- not determined 

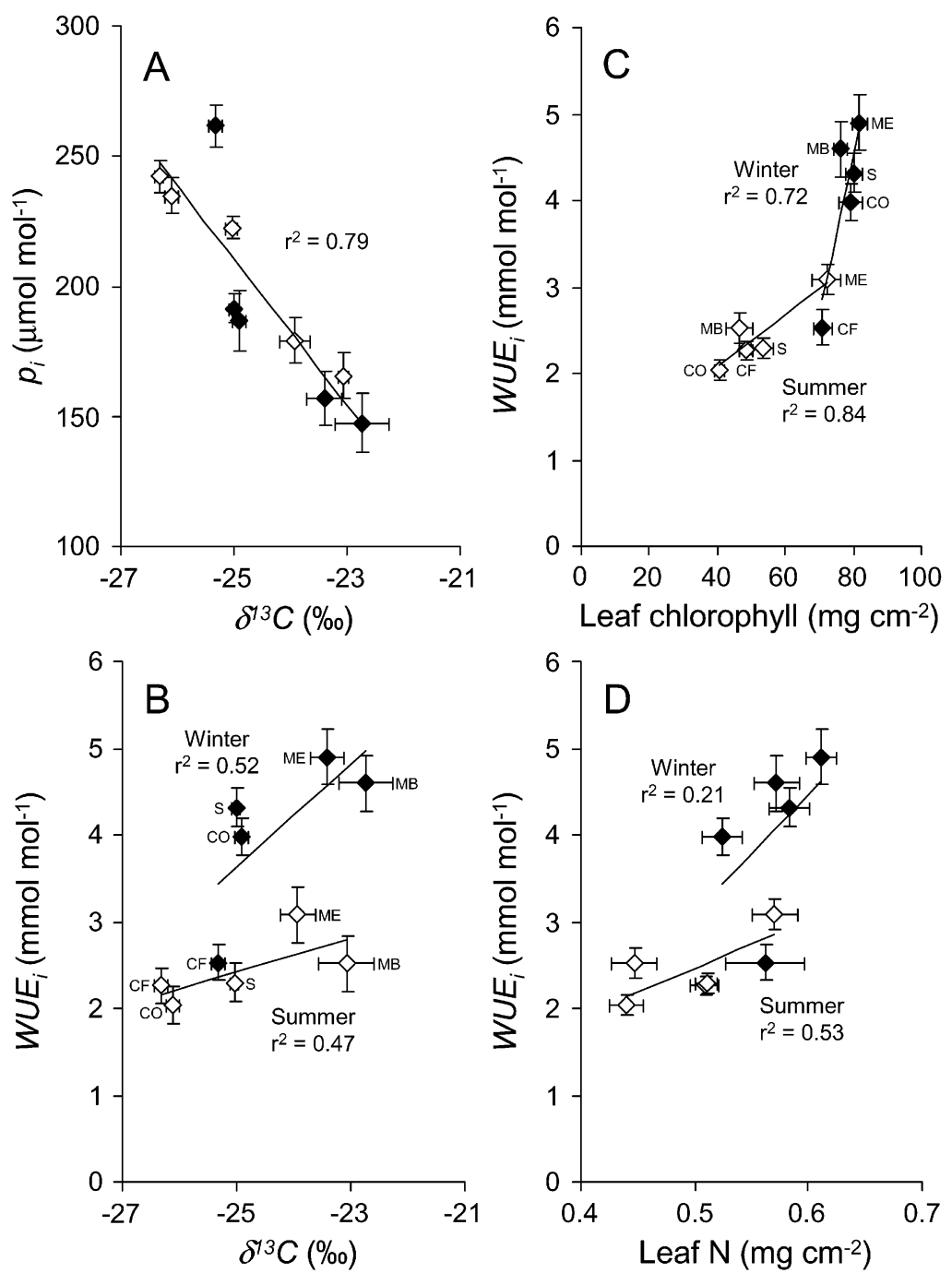

Figure 6. Relationships for Eucalyptus kochii subsp. plenissima at Kalannie, Western Australia, between $\delta^{13} \mathrm{C}$ of newly formed shoot tips, mean substomatal $\mathrm{CO}_{2}$ concentrations, $p_{i}$, intrinsic water-use efficiency, $W U E_{i}$, and leaf chlorophyll or nitrogen content. Data for $p_{i}$ and $W U E_{i}$ are means from fully-expanded, light-saturated leaves and all data refers either to summer months (open symbols) or winter months (closed symbols) for each treatment: MB, mature trees within remnant bush; ME, mature trees on edge bordering cleared land; S, CF \& $\mathrm{CO}$, trees belt-planted through paddocks either left as uncut saplings, or coppiced in February 1999 or in October 1999, respectively. Data for coppices are presented separately for the first and subsequent years after decapitation, denoted 1 and 2 , respectively. Bars indicate \pm one standard error.

saplings. In a similar fashion, DeSouza et al. (1986) demonstrated that Rhus resprouting after fire increased in leaf $\mathrm{N}$ and chlorophyll content which translated into elevated photosynthetic rates compared to those found in unburnt canopies.

Our study suggests that the thick leaves of E. kochii naturally confer high inherent photosynthetic capacity under environmental conditions severely repressive to $g_{s}$ (e.g. see Parkhurst, 1994). Reduced leaf thickness of relatively young coppice foliage would then be ex- pected to confer lower rates of photosynthesis on a leaf area basis (Figure 6), but having the beneficial effect of allowing newly formed photosynthates to be invested into a greater total area of new leaf, with progressive benefits in terms of overall growth rate. Although only strictly related to the leaf level here, this finding stands in contrast to the general concept of photosynthetic capacity being positively correlated with growth rates (Clearwater and Meinzer, 2001; Farquhar et al., 1989b; Hubick, 1990; Xu et al., 2000). 
Despite the large variation in tree size and habitat conditions, leaf level water-use efficiency during carbon assimilation $\left(W U E_{i}\right)$ varied to a relatively small degree (1.5-fold) between treatment means. This is consistent with the general tendency for instantaneous water-use efficiency of woody species to be conservatively expressed across environments (Guy and Holowachuk, 2001; Osório et al., 1998; Pettigrew and Meredith, 1994; Silim et al., 2001). $W U E_{i}$ of E. kochii was well correlated with both $g_{s}$ and leaf photosynthetic capacity in terms of leaf chlorophyll or $\mathrm{N}$ concentration. Thus, low $g_{s}$ of mature inner-bush and edge trees were associated with good $W U E_{i}$, while saplings were intermediate and coppices showed poorest $W U E_{i} . \delta^{13} \mathrm{C}$ signatures of new shoot tips amongst treatments were also well correlated with $g_{s}$ as expected of the mutual relationship with $p_{i}$ (Farquhar et al., 1982). The correlation between chlorophyll contents and $W U E_{i}$ was also consistent with the formulae of Farquhar et al. (1982) since higher photosynthetic capacity should decrease $p_{i}$ and increase $W U E_{i}$ at any given stomatal conductance (e.g. see Hubick, 1990).

However, interpretations of time courses of shoot tip $\delta^{13} \mathrm{C}$ for running measures of water stress and water-use efficiency for E. kochii appeared to be complicated by possible seasonal remobilisation of root starch reserves source (as suggested for tropical species by Terwilliger, 1997; Terwilliger et al., 2001). Starch has often been shown to possess less negative $\delta^{13} \mathrm{C}$ values than other plant fractions (Gleixner et al., 1993; Jäggi et al., 2002; Picon et al., 1997; Terwilliger et al., 2001) as also found here, and is known also to be involved in phases of rapid shoot extension in E. kochii (Wildy and Pate, 2002). Assuming that remobilisation of carbon occurred with little change in isotope composition, new season shoots did appear to be dominated initially by the more enriched $\delta^{13} \mathrm{C}$ signal of starch until currently produced photosynthates became the major carbon source later in the growth flush (Figure 5A). Our shading experiment of coppiced trees further suggested that starch might impact on shoot tip $\delta^{13} \mathrm{C}$ for up to 5 months when alternative carbon sources were scarce.

There was a large discrepancy which resulted when values for $W U E_{i}$ of leaves based on gas exchange were compared with values obtained at the whole-plant level. Coppiced trees proved to be most water-use efficient in dry matter production $\left(W U E_{D M}\right)$ despite showing similar $W U E_{i}$ values to uncut saplings. High water-use efficiency at the whole-plant (shoot) level was also reported for coppiced versus intact mallee eucalypts by Eastham et al. (1994), and by Lindroth and Cienciala (1996) for coppiced willows (Salix sp.).

The principal reason which we suggest for the high $W U E_{D M}$ of coppiced trees is that they were utilising a pre-formed root system (Wildy and Pate, 2002) and partitioning photosynthates preferentially to shoots and only sparingly to roots (see also Figure 2), while also generating little new stem tissue per unit leaf mass (Wildy et al., in press). Added to this, the thinner leaves produced by coppices decreased the unit carbon cost of leaf construction. These features together promote fast growth per unit of water transpired and may therefore have effected the high value for $W U E_{D M}$ (see also Binkley et al., in press). Also acting in favour of $W U E_{D M}$, coppiced trees were likely to be relatively non-water stressed due to their small area of foliage relative to root catchment (Kruger and Reich, 1993; Wildy et al., in press) and would therefore need to invest minimal amounts of carbon in extending new roots. Deployment of preformed root carbohydrate reserves in canopy regeneration may also act to increase $W U E_{D M}$, albeit only in the early stages of new shoot formation. Overall, we suggest that a combination of these whole-tree partitioning factors resulted in high $W U E_{D M}$ for coppice, overriding the leaf level effect of lower water stress acting to decrease $W U E_{i}$.

For similar reasons, relationships between $\delta^{13} \mathrm{C}$ and $W U E_{D M}$ were poorly defined (see also Le Roux et al., 1996; Olbrich et al., 1993). On the other hand, the relationship between $\delta^{13} \mathrm{C}$ and $W U E_{i}$ was strong for E. kochii (as for a number of tree species, e.g. Osório and Pereira, 1994; Silim et al., 2001; Zhang et al., 1993). The difference is due to both $W U E_{i}$ and $W U E_{D M}$ being based on the same transpiration loss, while the carbon fixed in foliage and used in calculation of $W U E_{i}$ may then be partitioned very differently in dry matter production and respiration of non-photosynthetic tissues in trees of different species, age and environmental circumstance (see also Osório et al., 1998).

To summarise in terms of our initial hypotheses, mature E. kochii mallees of relic bushland exhibited high water stress and showed low $g_{s}$ yet were still able to photosynthesise slowly due to an inherently high leaf photosynthetic capacity. Instantaneous water-use efficiency in carbon assimilation by their foliage was accordingly high but since little new shoot growth occurred, water-use efficiency remained low on a whole-shoot basis. Presumably the carbon assimilated was incorporated into new root biomass or 
respired in a high proportional expenditure in metabolism relative to growth. Mature trees on the edge of the bush were substantially larger but showed only marginally reduced water stress. They also showed low $g_{s}, A$ and whole-shoot water-use efficiency indicating only short-term benefit from access to additional water in the adjacent paddock. If trees of this size and age provide an accurate simulation of long-uncut tree belts through paddocks, one would anticipate a poor situation in respect of efficient use of scarce water resources. In contrast, alley-planted saplings with smaller canopies showed low water stress, high $g_{s}, A$, relative growth rates and whole-plant water-use efficiency. Coppices showed even less water stress, and least water-use efficiency in carbon fixation since physiology was geared for maximum growth rates. With carbon allocation favouring expansion of leaf area over investment into root or stem biomass, rapidly growing coppices were highly wateruse efficient in biomass production. Viewed in this manner, short-rotation coppicing of drought adapted trees such as E. kochii would constitute a particularly effective means of producing biomass in water limited environments.

\section{Acknowledgements}

We thank I. and R. Stanley for the use of the site, the many volunteers who assisted in data collection, and L. Bednarek for isotope analyses. The research was funded primarily by the Rural Industries Research and Development Corporation, Australia, and also by the Department of Conservation and Land Management, Western Australia, and the Land Institute, Kansas, USA.

\section{References}

Allen S J, Hall R L and Rosier P T W 1999 Transpiration by two poplar varieties grown as coppice for biomass production. Tree Physiol. 19, 493-501.

Andrew A H, Noble I R and Lange R T 1979 A non-destructive method for estimating the weight of forage shrubs. Aust. Rangel. J. 1, 777-782.

Bassman J H and Dickman D I 1982 Effects of defoliation in the developing leaf zone on young Populus $\times$ euramericana plants. I. Photosynthetic physiology, growth, and dry weight partitioning. For. Sci. 28, 599-612.

Beard J S 1984 Biogeography of the kwongan. In Kwongan: plant life of the sandplain. Eds. J S Pate and J S Beard. pp. 1-26. University of Western Australia Press, Perth.
Bennett L T, Weston C J and Attiwill P M 1997 Biomass, nutrient content and growth response to fertilisers of six-year-old Eucalyptus globulus plantations at three contrasting sites in Gippsland, Victoria. Aust. J. Bot. 45, 103-121.

Binkley D, Stape J L and Ryan M G in press Thinking about efficiency of resource use in forests. For. Ecol. Manage.

Blake T J 1983 Coppice systems for short-rotation intensive forestry: the influence of cultural, seasonal and plant factors. Aust. For. Res. 13, 279-291.

Blake T J 1980 Effects of coppicing on growth rates, stomatal characteristics and water relations in Eucalyptus camaldulensis Dehn. Aust. J. Plant Physiol. 7, 81-87.

Bradshaw A D 1965 Evolutionary significance of phenotypic plasticity in plants. Adv. Genet. 13, 115-155.

Clearwater M J and Meinzer F C 2001 Relationships between hydraulic architecture and leaf photosynthetic capacity in nitrogenfertilized Eucalyptus grandis trees. Tree Physiol. 21, 683-690.

Daniel T W, Helms J A and Baker F S 1979 Principles of silviculture. McGraw-Hill, New York. 500 p.

DeSouza J, Silka P A and Davis S D 1986 Comparative physiology of burned and unburned Rhus laurina after chaparral wildfire. Oecologia 71, 63-68.

Eastham J, Scott P R and Steckis R A 1994 Components of the water balance for tree species under evaluation for agroforestry to control salinity in the wheatbelt of Western Australia. Agrofor. Syst. 26, 157-169.

Enecon Pty Ltd. 2001 Integrated tree processing of mallee eucalypts. Report No. 01/160. Rural Industries Research and Development Corporation, Canberra. 92 p.

Farquhar G D, Ehleringer J R and Hubick K T 1989a Carbon isotope discrimination and photosynthesis. Annu. Rev. Plant Physiol. Plant Mol. Biol. 40, 503-537.

Farquhar G D, Hubick K T, Condon A G and Richards J H 1989b Carbon isotope discrimination and plant water-use efficiency. In Stable isotopes in ecological research. Eds. J R Rundel, J R Ehleringer and K A Nagy. pp. 21-40. Springer-Verlag, New York.

Farquhar G D, O'Leary M H and Berry J A 1982 On the relationship between carbon isotope discrimination and the intercellular carbon dioxide concentration in leaves. Aust. J. Plant Physiol. 9, 121-137.

Fleck I, Diaz C, Pascual M and Iniguez F J 1995 Ecophysiological differences between first-year resprouts after wildfire and unburned vegetation of Arbutus unedo and Coriaria myrtifolia. Acta Oecol. 16, 55-69.

Gibson A, Bachelard E P and Hubick K T 1994 Growth strategies of Eucalyptus camaldulensis Dehnh. at three sites in northern Australia. Aust. J. Plant Physiol. 21, 653-662.

Gleixner G, Danier H-J, Werner R A and Schmidt H-L 1993 Correlations between the ${ }^{13} \mathrm{C}$ content of primary and secondary plant products in different cell compartments and that in decomposing Basidiomycetes. Plant Physiol. 102, 1287-1290.

Grigg A M, Pate J S and Unkovich M J 2000 Responses of native woody taxa in Banksia woodland to incursion of groundwater and nutrients from bordering agricultural land. Aust. J. Bot. 48, $777-792$.

Guy R D and Holowachuk D L 2001 Population differences in stable carbon isotope ratio of Pinus contorta Dougl. ex Loud.: relationship to environment, climate of origin, and growth potential. Can. J. Bot. 79, 274-283.

Hatton T J, Moore S J and Reece P H 1995 Estimating stand transpiration in a Eucalyptus populnea woodland with the heat pulse method: measurement errors and sampling strategies. Tree Physiol. 15, 219-227. 
Hodgkinson K C 1992 Water relations and growth of shrubs before and after fire in a semi-arid woodland. Oecologia 90, 467-473.

Honeysett J L, Beadle C L and Turnbull C R A 1992 Evapotranspiration and growth of two contrasting species of eucalypts under non-limiting and limiting water availability. For. Ecol. Manage. 50, 203-216.

Hubick K T 1990 Effects of nitrogen source and water limitation on growth, transpiration efficiency and carbon-isotope discrimination in peanut cultivars. Aust. J. Plant Physiol. 17, 413-430.

Jäggi M, Saurer M, Fuhrer J and Siegwolf R 2002 The relationship between the stable carbon isotope composition of needle bulk material, starch, and tree rings in Picea abies. Oecologia 131, 325-332.

Jones M M, Turner N C and Osmond C B 1981 Mechanisms of drought resistance. In The physiology and biochemistry of drought resistance in plants. Eds. L G Paleg and D Aspinall. pp. 15-37. Academic Press, Sydney.

Karschon R 1971 The effect of coppice cutting on the water balance of Eucalyptus camaldulensis Dehn. Isr. J. Agric. Res. 21, 115126.

Kauppi A, Kivinitty M and Ferm A 1988 Growth habits and crown architecture of Betula pubescens Ehrh. of seed and sprout origin. Can. J. For. Res. 18, 1603-1613.

Kauppi A, Kivinitty M and Ferm A 1990 Leaf morphology and photosynthetic rate in birch seedlings and stump sprouts. Can. J. For. Res. 20, 952-960.

Köstner B, Falge E and Tenhunen J D 2002 Age-related effects on leaf area/sapwood area relationships, canopy transpiration and carbon gain of Norway spruce stands (Picea abies) in the Fichtelgebirge, Germany. Tree Physiol. 22, 567-574.

Kruger E L and Reich P B 1993 Coppicing alters ecophysiology of Quercus rubra saplings in Wisconsin forest openings. Physiol. Plant. 89, 741-750.

Ladiges P Y 1974 Variation in drought tolerance in Eucalyptus viminalis Labill. Aust. J. Bot. 22, 489-500.

Le Roux D, Stock W D, Bond W J and Maphanga D 1996 Dry mass allocation, water use efficiency and $\delta^{13} \mathrm{C}$ in clones of Eucalyptus grandis, E. grandis $\times$ camaldulensis and E. grandis $\times$ nitens grown under two irrigation regimes. Tree Physiol. 16, 497-502.

Li C 1999 Carbon isotope composition, water use efficiency and biomass productivity of Eucalyptus microtheca populations under different water supplies. Plant Soil 214, 165-171.

Lichtenthaler H K 1987 Chlorophylls and carotenoids: pigments of photosynthetic biomembranes. Methods Enzymol. 148, 350382

Lindroth A and Cienciala E 1996 Water use efficiency of shortrotation Salix viminalis at leaf, tree and stand scales. Tree Physiol. 16, 257-262.

Liu Z, Chen J, Percy R G, Sharifi M R, Rundel P W and Zeiger E 1996 Genetic variation in carbon isotope discrimination and its relation to stomatal conductance in Pima cotton (Gossypium barbadense). Aust. J. Plant Physiol. 23, 127-132.

Mappin K A, Pate J S and Bell T L 2003 Productivity and water relations of burnt and long-unburnt semi-arid shrubland in Western Australia. Plant Soil 257, 321-340.

McJannet D and Vertessy R 2001 Effects of thinning on wood production, leaf area index, transpiration and canopy interception of a plantation subject to drought. Tree Physiol. 21, 1001-1008.

Myers B A and Neales T F 1984 Seasonal changes in the water relations of Eucalyptus behriana and Eucalyptus microcarpa in the field. Aust. J. Bot. 32, 495-510.

Noble J C 2001 Lignotubers and meristem dependence in mallee (Eucalyptus spp.) coppicing after fire. Aust. J. Bot. 49, 31-41.
Nulsen R A, Bligh K J, Baxter I N, Solin E J and Imrie D H 1986 The fate of rainfall in a mallee and heath vegetated catchment in southern Western Australia. Aust. J. Ecol. 11, 361-371.

Olbrich B W, Le Roux D, Poulter A G, Bond W J and Stock W D 1993 Variation in water use efficiency and $\delta^{13} \mathrm{C}$ levels in Eucalyptus grandis clones. J. Hydrol. 150, 615-633.

Osório J, Osório M L, Chaves M M and Pereira J S 1998 Effects of water deficits on ${ }^{13} \mathrm{C}$ distribution and transpiration efficiency of Eucalyptus globulus clones. Aust. J. Plant Physiol. 25, 645-653.

Osório J and Pereira J S 1994 Genotypic differences in water use efficiency and ${ }^{13} \mathrm{C}$ discrimination in Eucalyptus globulus. Tree Physiol. 14, 871-882.

Parkhurst D F 1994 Tansley review no. 65: diffusion of $\mathrm{CO}_{2}$ and other gases inside leaves. New Phytol. 126, 449-479.

Pate J S, Froend R H, Bowen B J, Hansen A and Kuo J 1990 Seedling growth and storage characteristics of seeder and resprouter species of Mediterranean-type ecosystems of S.W. Australia. Ann. Bot. 65, 585-601.

Pettigrew W T and Meredith W R, Jr 1994 Leaf gas exchange parameters vary among cotton genotypes. Crop Sci. 34, 700-705.

Picon C, Ferhi A and Guehl J-M 1997 Concentration and $\delta^{13} \mathrm{C}$ of leaf carbohydrates in relation to gas exchange in Quercus robur under elevated $\mathrm{CO}_{2}$ and drought. J. Exp. Bot. 48, 1547-1556.

Pinkard E A, Battaglia M, Beadle C L and Sands P J 1999 Modeling the effects of physiological responses to green pruning on net biomass production of Eucalyptus nitens. Tree Physiol. 19, 1-12.

Prior L D, Eamus A and Duff G A 1997 Seasonal and diurnal patterns of carbon assimilation, stomatal conductance and leaf water potential in Eucalyptus tetradonta saplings in a wet-dry savanna in northern Australia. Aust. J. Bot. 45, 241-258.

Pucher G W, Leavenworth C S and Vickery H B 1948 Determination of starch in plant tissues. Anal. Chem. 20, 850-853.

Ritchie G A and Hinckley T M 1975 The pressure chamber as an instrument for ecological research. Adv. Ecol. Res. 9, 165-254.

Rundel P W, Specht R L, Hopkins A J M, Montenegro G and Margaris N S 1988 Foliar analyses. In Mediterranean-type ecosystems. A data source book. Ed. R L Specht. pp. 63-80. Kluwer Academic Publishers, Dordrecht.

Saranga Y, Flash I and Yakir D 1998 Variation in water-use efficiency and its relation to carbon isotope ratio in cotton. Crop Sci. 38, 782-787.

Scholander P F, Hammel H T, Bradstreet E D and Hemmingsen E A 1965 Sap pressure in vascular plants. Science 148, 339-346.

Sefton C A, Montagu K D, Atwell B and Conroy J P 2002 Anatomical variation in juvenile eucalypt leaves accounts for differences in specific leaf area and $\mathrm{CO}_{2}$ assimilation rates. Aust. J. Bot. 50, $1-10$

Sennerby-Forsse L, Ferm A and Kauppi A 1992 Coppicing ability and sustainability. In Ecophysiology of short rotation forest crops. Eds. C P Mitchell, J B Ford-Robertson, T Hinckley and L Sennerby-Forsse. pp. 146-184. Elsevier Science Publishers Ltd, Essex.

Silim S N, Guy R D, Patterson T B and Livingston N J 2001 Plasticity in water use efficiency of Picea sitchensis, P. glauca and their natural hybrids. Oecologia 128, 317-325.

Sims R E H, Senelwa K, Maiava T and Bullock B T 1999 Eucalyptus species for biomass energy in New Zealand - Part II: Coppice performance. Biomass Bioenergy 17, 333-343.

Sparks J P and Black R A 1999 Regulation of water loss in populations of Populus trichocarpa: the role of stomatal control in preventing xylem cavitation. Tree Physiol. 19, 453-459.

Specht R L and Rundel P W 1990 Sclerophylly and foliar nutrient status of Mediterranean-climate plant communities in southern Australia. Aust. J. Bot. 38, 459-474. 
Stoneman G L, Turner N C and Dell B 1994 Leaf growth, photosynthesis and tissue water relations of greenhouse-grown Eucalyptus marginata seedlings in response to water deficits. Tree Physiol. 14, 633-646.

Terwilliger V J 1997 Changes in the $\delta^{13} \mathrm{C}$ values of trees during a tropical rainy season: some effects in addition to diffusion and carboxylation by Rubsico? Am. J. Bot. 84, 1693-1700.

Terwilliger V J, Kitajima K, Le Roux-Swarthout D J, Mulkey S and Wright S J 2001 Intrinsic water-use efficiency and heterotrophic investment in tropical leaf growth of two neotropical pioneer tree species as estimated from $\delta^{13} \mathrm{C}$ values. New Phytol. 152, 267281.

Tschaplinski T J and Blake T J 1989 Photosynthetic reinvigoration of leaves following shoot decapitation and accelerated growth of coppice shoots. Physiol. Plant. 75, 157-165.

Tyson M, Vaillancourt R E and Reid J B 1998 Determination of clone size and age in a mallee eucalypt using RAPDs. Aust. J. Bot. 46, 161-172.

Walker C D, Brunel J P, Dunin F X, Edwards W R N, Hacker J M, Hartmann J, Jupp D L, Reyenga W, Schwerdtfeger P, Shao Y and Williams A E 1990 A joint project on the water use of a mallee community in late summer. In The mallee lands - a conservation perspective. Eds. J C Noble, P J Joss and G K Jones. pp. 114-119. CSIRO, Melbourne.

Wildy D T and Pate J S 2002 Quantifying above- and belowground growth responses of the Western Australian oil mallee, Eucalyptus kochii subsp. plenissima, to contrasting decapitation regimes. Ann. Bot. 90, 185-197.

Wildy D T, Pate J S and Bartle J R 2004 Budgets of water use by Eucalyptus kochii tree belts in the semi-arid wheatbelt of Western Australia. Plant Soil 262, 129-149.

Xu Z H, Saffigna P G, Farquhar G D, Simpson J A, Haines R J, Walker S, Osborne D O and Guinto D 2000 Carbon isotope discrimination and oxygen isotope composition in clones of the $\mathrm{F}_{1}$ hybrid between slash pine and Caribbean pine in relation to tree growth, water-use efficiency and foliar nutrient concentration. Tree Physiol. 20, 1209-1217.

Zhang L, Marshall J D and Jaquish B C 1993 Genetic differentiation in carbon isotope discrimination and gas exchange in Pseudotsuga menziesii. Oecologia 93, 80-87.

Section editor: M.A. Adams 